\title{
Effect of Various Supercharger Boost Pressure to in-Cylinder Pressure and Heat Release Rate Characteristics of Direct Injection Diesel Engine at Various Engine Rotation
}

\author{
Willyanto Anggono ${ }^{1,2,3}$, Wataru Ikoma ${ }^{1}$, Haoyu Chen $^{1}$, Zhiyuan Liu ${ }^{1}$, \\ Mitsuhisa Ichiyanagi ${ }^{1, *}$ and Takashi Suzuki ${ }^{1}$ \\ ${ }^{1}$ Department of Engineering and Applied Sciences, Sophia University, Tokyo 102-8554, Japan \\ ${ }^{2}$ Mechanical Engineering Department, Petra Christian University, Jl. Siwalankerto No.121-131, \\ Surabaya 60236, Indonesia \\ ${ }^{3}$ Centre for Sustainable Energy Studies, Petra Christian University, J1. Siwalankerto No.121-131, \\ Surabaya 60236, Indonesia
}

\begin{abstract}
The diesel engines are superior in terms of power efficiency and fuel economy compared to gasoline engines. In order to optimize the performance of direct injection diesel engine, the effect of various intake pressure (boost pressure) from supercharging direct injection diesel engine was studied at various engine rotation. A single cylinder direct injection diesel engine was used in this experiment. The bore diameter of the engine used was set to $85 \mathrm{~mm}$, the stroke length was set to $96.9 \mathrm{~mm}$, and the compression ratio was set to 16.3 . The variation of engine rotation started from $800 \mathrm{rpm}$ to $2000 \mathrm{rpm}$ with $400 \mathrm{rpm}$ increment. The variation of boost pressure is bounded from $0 \mathrm{kPa}$ boost pressure (naturally aspirated) to the maximum of $60 \mathrm{kPa}$ boost pressure with $20 \mathrm{kPa}$ boost pressure increment. The performance of the engine is evaluated in terms of in-cylinder pressure and heat release rate as the most important performance characteristics of the diesel engine. The in-cylinder pressure and heat release rate of direct injection diesel engine are increased with the elevation of boost pressure at various engine rotation. The raise of engine rotation resulted in the decrease of maximum in-cylinder pressure and heat release rate.
\end{abstract}

Key words: Diesel engine, efficiency, engine performace, injection strategy.

\section{Introduction}

With the advancement of technology, the demand for energy in society raises. Coupled with the depletion of fossil fuel and the increasing of human dependency towards it, it is reasonable to assume that the demand for energy will be higher than the available supply of it. To maintain functioning society in the future, the awareness and applicable solutions for this issue are becoming more relevant than before [1]. In order to prevent energy crisis to

*Corresponding author: ichiyanagi@sophia.ac.jp 
eventuate, many methods have been devised. Most known method is the use of renewable fuel like biogas, biodiesel from edible and non-edible source, and briquette which are cheaper and beneficial in economy aspect [2-6]. Another method is to raise the efficiency of instrument used to produce energy. As one of the most used technology for utilizing fossil fuel, car engines become suitable objects to investigate in order to maximize its efficiency by upgrading their performance output.

Compared to gasoline engine, diesel engine has lower fuel consumption and higher power efficiency. The lean mixture of fuel, independency from throttling device, and high compression ratio play a huge part in giving diesel engine these advantages. Because of diesel engine's superiority compared to gasoline engine, vehicles with diesel engine are highly desired. With such advantages over gasoline engine and its raising popularity, diesel engine is selected to be studied and developed further.

There are many ways to increase the diesel engine performance. Some known methods are by maintaining optimal air fuel ratio, oxygen availability, proper level of injected fuel, deciding the optimum injector location for engine design and coupling engine with supercharger [7, 8]. Supercharging are known as a method to increase the performance of an engine by increasing its intake pressure. Many studies have been conducted in investigating the effect of supercharging in combustion engine [9]. Some studies have suggested the reduction of fuel consumption and BSFC (brake specific fuel consumption) with the use of supercharging and several studies have also shown the increase of engine power, brake power, and specific power output under supercharged condition [10-14].

Another important parameter in engine performance is the heat release rate. Studies for engine heat release rate and increased intake pressure have been conducted by several researchers [7, 9]. Jayashankara et al. [9] investigated this phenomenon using Computational Fluid Dynamic in direct injection diesel engine. The use of numerical simulation for studying in-cylinder phenomena has been deemed as important for both designing and improving the engine design.

Although several studies have been done in investigating the effect of supercharging in combustion engine performance and emissions, more holistic researches regarding its effect in the engine are required. While supercharging is known to increase the performance of an engine, perhaps at some point, excessive intake pressure of engine will reduce the performance of the engine. Such condition is presumed because supercharging causes lean combustion in an engine [14]. To understand the characteristic of supercharging while also maximizing its potential, this study tried to find the effect of intake pressure (boost pressure) in regards with the engine performance.

The heat release rate of the fuel toward engine cylinder is studied because it causes a variation of gas pressure and temperature within the engine cylinder. It strongly affects the fuel economy, power output, gas exchange, emissions, and working processes of the IC engine $[9,15-18]$. Heat release rate provides a good insight into the combustion process that takes place in the engine.

\section{Experimental setups}

The bore specification of the engine was $85 \mathrm{~mm}$ in diameter, the stroke length was $96.9 \mathrm{~mm}$, and the compression ratio was 16.3. The cylinder head and the piston are made of an aluminum alloy, and the cylinder liner is a dry liner made of cast iron. Schematic diagram of the experimental system is shown in Figure 1. The specifications of the single cylinder diesel engine used are shown in Table 1. The measurement instruments used for measuring In-cylinder pressure was Sensor Kistler Japan Type 6052.

In obtaining the heat release rate, the signal from the high-speed response coaxial heat flux meter and the coaxial thermocouple installed in the engine was amplified and recorded. 
The records were stored in the data logger together with the signal of the in-cylinder pressure sensor for every crank angle (CA).

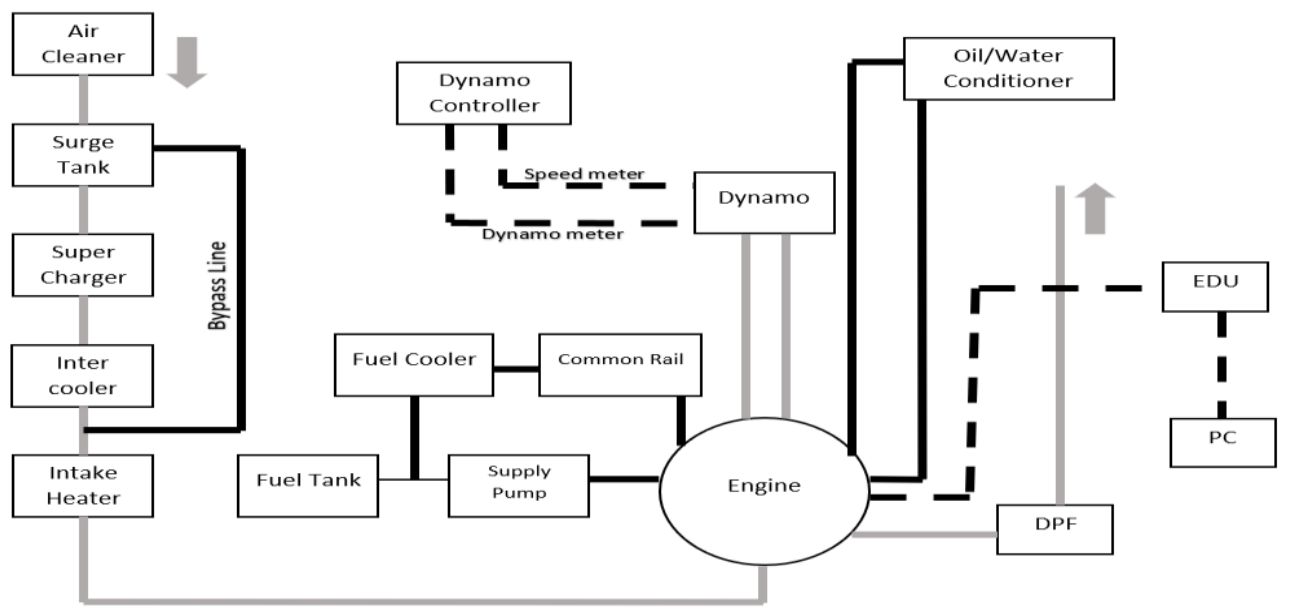

Fig. 1. Schematic diagram of the experimental system.

Table 1. Engine and measurement instrument specification.

\begin{tabular}{|l|l|}
\hline \multicolumn{1}{|c|}{ Engine } & \multicolumn{1}{c|}{ Single cylinder engine } \\
\hline Cylinder capacity [cc] & 550 \\
\hline Bore [mm] & 85 \\
\hline Stroke [mm] & 96.9 \\
\hline Connecting rod length [mm] & 150.46 \\
\hline Cylinder offset [mm] & 6.5 \\
\hline Piston-pin offset [mm] & 0.8 \\
\hline Compression ratio [-] & 16.3 \\
\hline Intake valve opening period [deg.] & From 347 to -120 (Comp. TDC is 0 deg.) \\
\hline Exhaust valve opening period [deg.] & From 122 to -330 (Comp. TDC is 0 deg.) \\
\hline
\end{tabular}

Table 2. Experimental conditions of the engine under various rotation speed.

\begin{tabular}{|c|c|c|c|c|}
\hline $\begin{array}{c}\text { Rotation } \\
\text { Speed } \\
\text { [rpm*] }\end{array}$ & $\begin{array}{c}\text { Injection } \\
\text { step }\end{array}$ & $\begin{array}{c}\text { Injection timing } \\
(\mathbf{d e g})\end{array}$ & $\begin{array}{c}\text { Injection } \\
\text { time (ms) }\end{array}$ & $\begin{array}{c}\text { Injection } \\
\text { quantity (g st }\end{array}$ \\
\hline \multirow{3}{*}{800} & pilot & -25 & 0.16 & 0.0014 \\
\cline { 2 - 5 } & pre & -15 & 0.18 & 0.0024 \\
\cline { 2 - 5 } & main & 3 & 0.83 & 0.0360 \\
\hline \multirow{3}{*}{1200} & pilot & -25 & 0.16 & 0.0014 \\
\cline { 2 - 5 } & pre & -15 & 0.18 & 0.0024 \\
\cline { 2 - 5 } & main & 3 & 0.83 & 0.0360 \\
\hline \multirow{3}{*}{200} & pilot & -25 & 0.16 & 0.0014 \\
\cline { 2 - 5 } & pre & -15 & 0.18 & 0.0024 \\
\cline { 2 - 5 } & main & 3 & 0.83 & 0.0360 \\
\cline { 2 - 5 } & pilot & -25 & 0.16 & 0.0014 \\
\cline { 2 - 5 } & pre & -15 & 0.18 & 0.0024 \\
\hline
\end{tabular}

*Note: $1 \mathrm{rpm}=1 / 60 \mathrm{~Hz}$ 
The experiment was conducted under various intake pressures (boost pressure) and various engine rotation. The intake pressures were boosted for $20 \mathrm{kPa}, 40 \mathrm{kPa}$, and $60 \mathrm{kPa}$ by using supercharger. Naturally aspirated condition $(0 \mathrm{kPa})$ was also investigated as basis to determine the impact of using supercharged in direct injection diesel engine. The engine rotation was varied from $800 \mathrm{rpm}$ to $2000 \mathrm{rpm}$ with $400 \mathrm{rpm}$ increment. The performance of the engine was evaluated in terms of cylinder pressure and heat release rate of the engine. These evaluation parameters were measured using the same condition of injection strategy (injection step, injection timing, injection time and injection quantity), as shown in Table 2 .

\section{Results and discussion}

The relationship between in-cylinder pressure and crank angle at various engine speed and supercharger boost pressure are shown in Figure 2, 3, 4, and 5. The increase of supercharger boost pressure leads to higher in-cylinder pressure for various engine rotation [(800, 1200,1600 and 2000$) \mathrm{rpm}]$. It can be seen from Figure 2, 3, 4, and 5 that the maximum in-cylinder pressure increases gradually from $0 \mathrm{kPa}$ boost pressure (naturally aspirated) to $60 \mathrm{kPa}$ boost pressure in all experimented engine speed of (800 to 2000$) \mathrm{rpm}$.

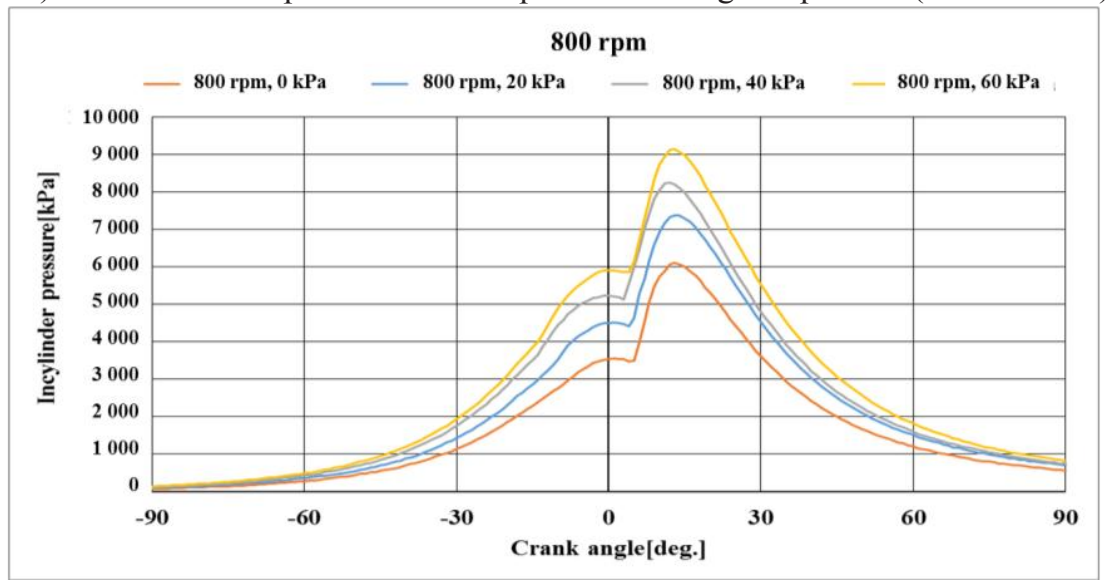

Fig. 2. In-cylinder pressure to crank angle at various boost pressures with engine rotation of $800 \mathrm{rpm}$.

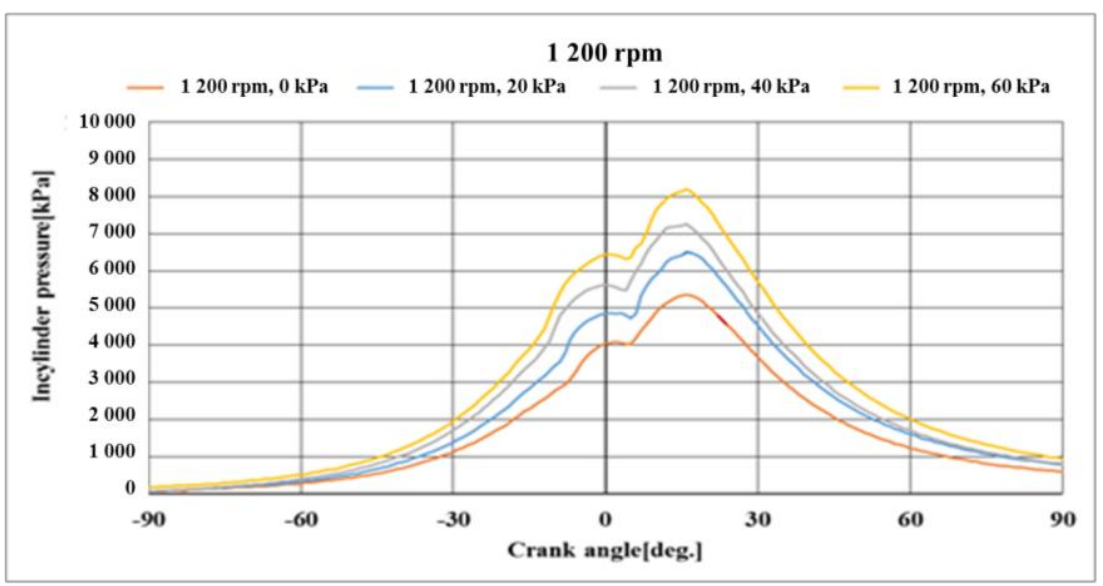

Fig. 3. In-cylinder pressure to crank angle at various boost pressures with engine rotation of $1200 \mathrm{rpm}$. 


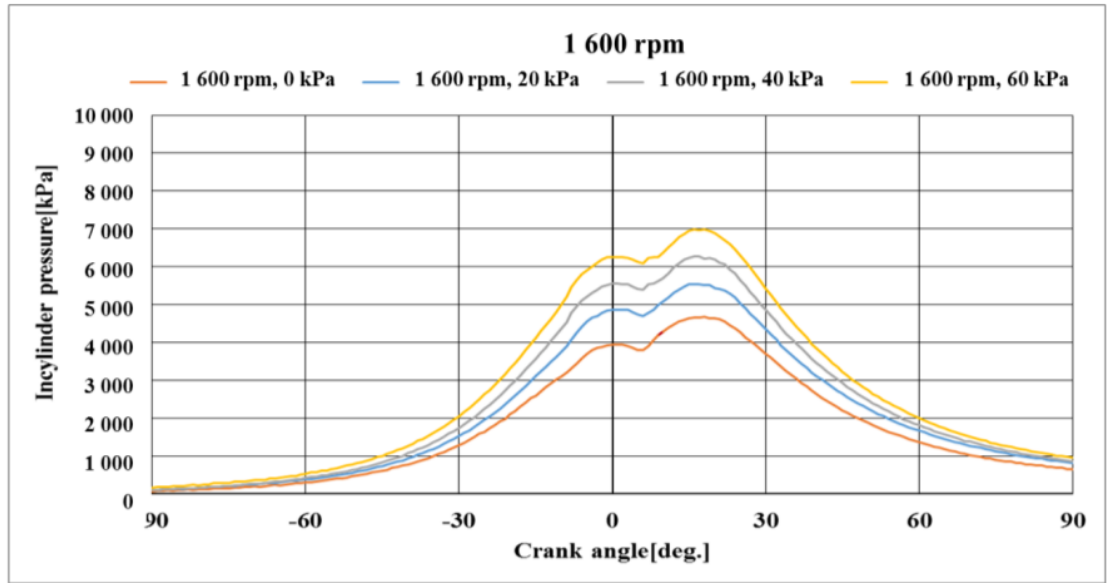

Fig. 4. In-cylinder pressure to crank angle at various boost pressures with engine rotation of $1600 \mathrm{rpm}$.

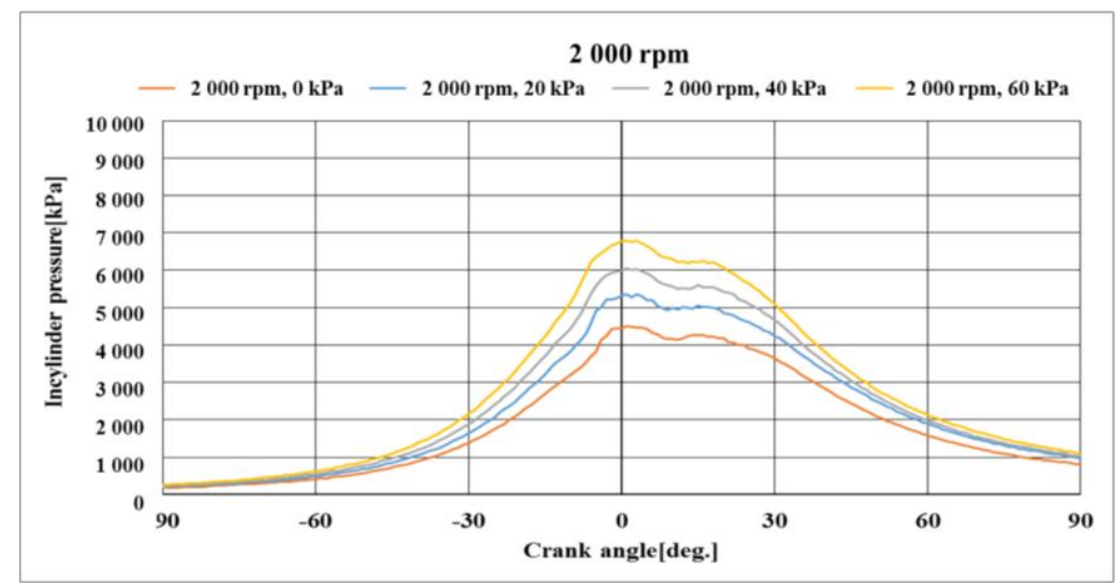

Fig. 5. In-cylinder pressure to crank angle at various boost pressures with engine rotation of $2000 \mathrm{rpm}$

At low engine rotation (speed), the in-cylinder pressure after TDC (Top Dead Centre) is much higher than the in-cylinder pressure during TDC. As the engine speed increases, the difference of in-cylinder pressure after TDC and in-cylinder pressure during TDC declines. The decline may reach to the point where the raising in-cylinder pressure after TDC is lower than in-cylinder pressure during TDC and shifts the location of maximum in-cylinder pressure. This phenomenon is caused by the timing of main fuel injection in $3^{\circ}$ after TDC. During such condition, the combustion reaction which induces the raise of in-cylinder pressure after TDC is occurring slower than it should be [19-21]. This phenomenon can be observed in $2000 \mathrm{rpm}$ engine speed condition where the raise of in-cylinder pressure during TDC is higher compared to subsequent peak of in-cylinder pressure after TDC.

The heat release rate to crank angle of direct injection diesel engine under various engine speed and intake pressures are shown in Figure 6, 7, 8, and 9. The higher intake pressure (boost pressure) leads to higher heat release rate in the engine for every engine speed [(800, 1200,1600 and 2000$) \mathrm{rpm}]$. The maximum heat release rate increases gradually from naturally aspirated ( $0 \mathrm{kPa}$ boost pressure) to $60 \mathrm{kPa}$ boost pressure at various engine rotation as shown Figure 6, 7, 8, and 9. It is also discovered that as the 
engine speed increases, the peak of heat release rate reduces and shifts toward the positive crank angle.

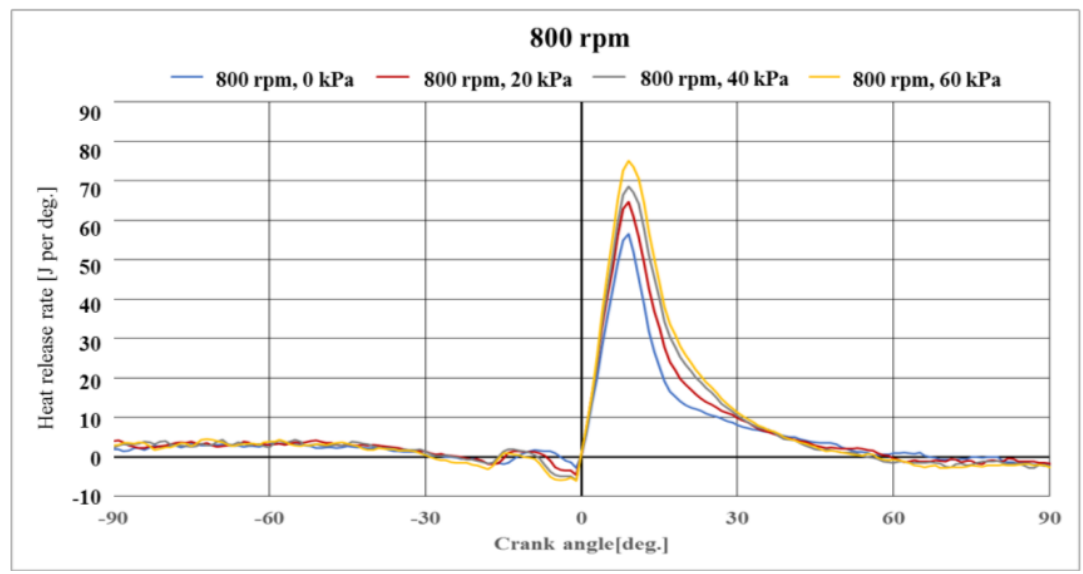

Fig. 6. Heat release rate to crank angle at various boost pressures with engine rotation of $800 \mathrm{rpm}$.

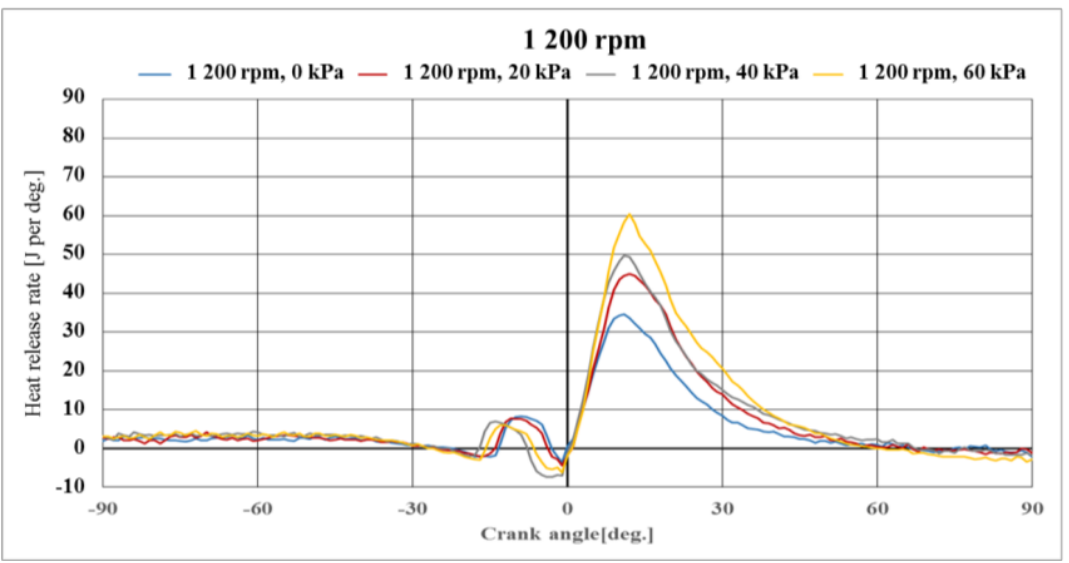

Fig. 7. Heat release rate to crank angle at various boost pressures with engine rotation of $1200 \mathrm{rpm}$.

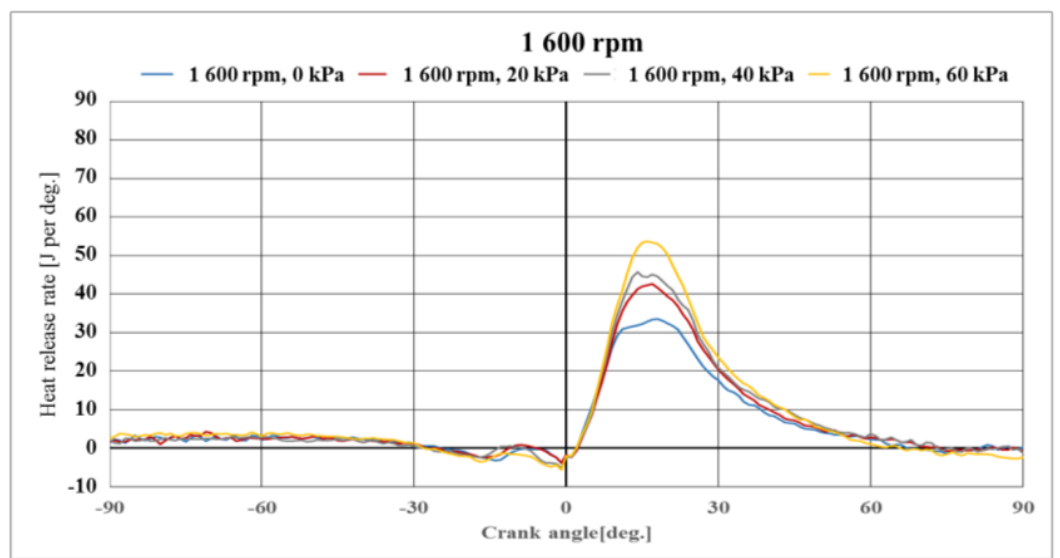

Fig. 8. Heat release rate to crank angle at various boost pressures with engine rotation of $1600 \mathrm{rpm}$. 


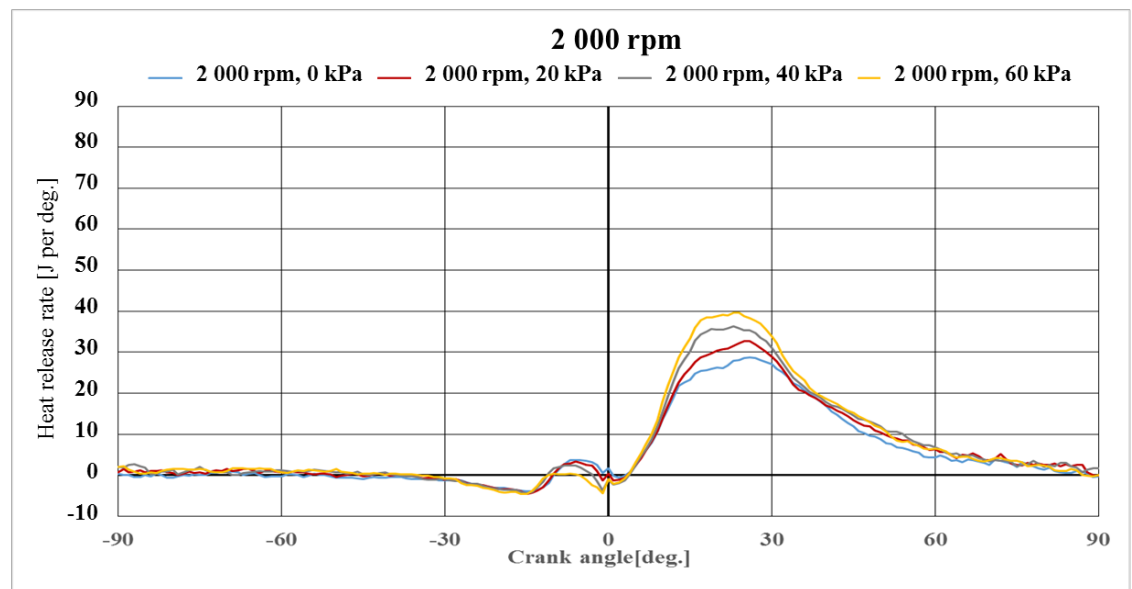

Fig. 9. Heat release rate to crank angle at various boost pressures with engine rotation of $2000 \mathrm{rpm}$.

\section{Conclusion}

The higher intake pressure from (0 to 60$) \mathrm{KPa}$ in direct injection diesel engine leads to higher in-cylinder pressure and heat release rate. With higher cylinder pressure and heat releases rate, the performance of the engine will increase. Supercharging direct injection diesel engine with additional intake pressure up to $60 \mathrm{kPa}$ boost pressure is a viable option to increase the performance of diesel engine. Additionally, it was discovered, in range of $800 \mathrm{rpm}$ to $2000 \mathrm{rpm}$, the increase of engine speed decreases the maximum in-cylinder pressure and heat release rate of the engine and alter their occurrence time.

In the future, by advancing the injection of fuel before TDC, the engine speed and the combustion speed in the engine will be balanced. With the balance between engine speed and combustion speed, the maximum in-cylinder pressure will occur near TDC. The discovery of this research will provide more insight regarding the optimal speed of supercharged engine and the degree of supercharging an engine. This study is expected to contribute to the development of a more efficient engine.

Many thanks to Sophia University, Japan and Petra Christian University, Indonesia for their supports during this research.

\section{References}

1. A.D.M. Guedes, S.L. Braga, F. Pradelle, Fuel, 225:174-183(2018). https://www.cheric.org/research/tech/periodicals/view.php?seq=1646186

2. W. Anggono, F.D. Suprianto, K. Purnomo, T.I. Hartanto, T.P. Wijaya, App. Mech. and Mate., 836:265-270(2016). https://www.scientific.net/AMM.836.265

3. B. Ashok, R.T.K. Raj, K. Nanthagopal, R. Krishnan, R. Subbarao, Energy Conv. Man., 139:110-121(2017).

https://www.researchgate.net/publication/314081167_Lemon_peel_oil_A_novel_renewable alternative_energy source for_diesel_engine

4. W. Anggono, F.D. Suprianto, Sutrisno, G.J. Gotama, J. Evander, A.W. Kasrun, ARPN J. of Eng. and App. Sci., 13,3:1080-1084(2018).

https://www.researchgate.net/publication/323470000_Investigation_on_biomass_briqu ette from_Cerbera_manghas waste twigs as renewable energy source 
5. A.A. Elshaib, M.M. Kamal, A.A. Elahwany, J. of the Ene. Inst., 87:11-17(2014). https://www.sciencedirect.com/science/article/pii/S1743967114000038

6. W. Anggono, Int. J. of Ren. Ene. Res., 7,1:304-310(2017). http://repository.petra.ac.id/17550/1/Publikasi1_98023 3253.pdf

7. M. Ichiyanagi, T. Suzuki, J. for Japan Soc. for Des. Eng., 51,9:659-670(2016). https://www.jstage.jst.go.jp/article/jjsde/51/9/51_2016.2681/_article/-char/en

8. K. Zha, S. Busch, P.C. Miles, S. Wijeyakulasuriya, S. Mitra, P.K. Senecal, SAE Int. J. of Eng., 8,4:1837-1855(2015). https://www.jstor.org/stable/26278081?seq=1\#page_scan tab contents

9. B. Jayashankara, V. Ganesan, Energy. Conv. and Man., 51:1835-1848(2010). https://www.sciencedirect.com/science/article/pii/S0196890409004269

10. D. Jagadish, P. Ravi Kumar, K.M. Murthy, Ther. Sci., 15,4:1165-1174(2011). http://thermalscience.vinca.rs/pdfs/papers-2011/TSCI100513042J.pdf

11. M. Karabektas, Renew. Energ., 34:989-993(2009). https://www.sciencedirect.com/science/article/pii/S0960148108003133

12. I. Al-Hinti, M. Samhouri, A. Al-Ghandoor, A. Sakhrieh, Appl. Energy, 86:113121(2009). https://www.infona.pl/resource/bwmeta1.element.elsevier-6a8e9dc0-8dc93f30-b9dd-0f8fdd5d03bd

13. H.G. Chaudhari, T.M. Patel, P.R. Paterl, IOSR-JMCE, 14,2:21-32(2017). http://www.iosrjournals.org/iosr-jmce/papers/vol14-issue2/Version-5/C1402051120.pdf

14. M.M. Roy, E. Tomita, N. Kawahara, Y. Harada, A. Sakane, Int. J. Hydro Energy, 34:7811-7822(2009).

https://www.sciencedirect.com/science/article/pii/S0360319909011203

15. K. Uchida, T. Suzuki, Y. Oguri, M. Yoshida. Precise measurement and analysis of heat transfer to the inlet air using intake port model: Influence of intake valve and unsteady effect. ASME 2006 International Mechanical Engineering Congress and Exposition (Chicago, Illinois, USA, 2006). ASME IMECE2006-14144:73-82(2006). http://proceedings.asmedigitalcollection.asme.org/proceeding.aspx?articleID $=1605059$

16. P. Sombatwong, P. Thauyasuit, K. Pianthong, Energy Proc., 34:218-227(2013). https://www.sciencedirect.com/science/article/pii/S1876610213009934

17. N.R. Banapurmath, R. Sankaran, A.V. Tumbal, T.N. Narasimhalu, A.M. Hunashyal, N.H. Ayachit, Int. J. of Auto. Eng. and Tech., 3,4:129-138(2014). https://dergipark.org.tr/download/article-file/89395

18. A. Wimmer, R. Pivec, T. Sams, Heat transfer to the combustion chamber and port walls of ic engines - measurement and prediction. SAE World Congress (Detroit, Michigan, 2000). SAE Tech. Paper, 2000-01-0568(2000). https://saemobilus.sae.org/content/2000-01-0568/

19. N. Raeie, S. Emami, O.K. Sadaghiyani, Prop. Power Res., 3,2:59-67(2014). https://www.sciencedirect.com/science/article/pii/S2212540X14000248

20. T. Ganapathy, R.P. Gakkhar, K. Murugesan, App. Energy, 88:4376-4386(2011). https://www.sciencedirect.com/science/article/pii/S0306261911003072

21. S.H. Park, I.M Youn, C.S. Lee, Fuel, 90:748-755(2011). https://www.sciencedirect.com/science/article/pii/S0016236110004515 